\title{
Yunus Emre'nin Şathiyelerini Bilinç Akışı ile Okumanın İmkânı Üzerine
}

\author{
Reading Yunus Emre's Shathiyas in Terms of Stream of Consciousness
}

\author{
Rabia Doğru*
}

Öz

Yunus Emre'nin şathiye türünde değerlendirilen şiirleri, birbiriyle anlam bakımından doğrudan uzlaşmayan, rasyonellikten uzak ve bu bağlamda farklı bir alımlama tarzını beraberinde getirmesi beklenen imgelerle kurulmuştur. Bu imgelerden hareketle, söz konusu şiirler hakkında öne sürülen yaklaşımların birçoğu, Yunus Emre'nin burada kasıtlı olarak sembolik bir dil kullandığı yönündedir. Yani bu şiirlerde üstü örtülü bir şekilde verilen kelimelerin, derinde tasavvufî düşüncenin kavramlarını barındırdığı; böylece onların, kavramsal bir dünyanın gösterilenleriyle tasarlandığı varsayılmaktadır. Ne var ki bu değerlendirmelerin çoğunlukla tasavvuf düşüncesinden hareketle yapılmış olması, Yunus Emre'nin bu türdeki şiirlerine tek yönlü yaklaşım alışkanlığını da beraberinde getirmiş gibidir. Bunun yanı sıra şathiye türündeki bir şiir ve bilinç akışıyla kurulmuş bir metin arasındaki benzerlikler, Yunus Emre'nin bu şiirlerini, bilinç akışı tekniği üzerinden ve farklı bir perspektifle okumanın çağrısı olarak görünmektedir. Bu çalışma, genel itibarıyla Yunus Emre'nin şathiyelerine yönelik şimdiye değin çoğunlukla benimsenen okuma alışkanlığını askıya almayı denemekte ve bunları, bilinç akışı kurgusuyla okumanın imkânı üzerinde durmaktadır.

\section{Anahtar Kelimeler}

Yunus Emre, Şathiye, Bilinç akışı, Şiir, Edebiyat

\begin{abstract}
Some of Yunus Emre's poems are built on images that do not reconcile directly with one another in terms of their meanings and are distant from rationality. Therefore, his poems are typically received by readers differently compared to other literary works. Such perceptions have been used as foundations for the development of various approaches to Yusuf Emre's poems, which are considered shathiya. These approaches are centered on the idea that in his poems, Yunus Emre has employed symbolic language with a definite rationale in mind. This approach suggests that the embedded phrases in his poems are based extensively on the tenets of Sufi philosophy. Consequently, it is presumed that the poems are constructed with allegories to the conceptual universe. However, the fact that all the commentaries on Yunus Emre's poems have been centered exclusively on the principles of Sufi philosophy has given rise to a one-sided consideration of his poetry. In addition, the similarities between the shathiya and stream-of-consciousness texts seem act as invitations for readers to interpret Yunus Emre's poems from the shathiya perspective. This study is an attempt at diverting readers from interpreting Yunus Emre's poems exclusively in the light of the shathiya-type poems and encouraging a shift in focus toward the possibility of reading these poems as works of stream-of-consciousness fiction.
\end{abstract}

\section{Keywords}

Yunus Emre, Shathiya, Stream of consciousness, Poem, Literature

* Sorumlu Yazar: Rabia Doğru, Bilecik Şeyh Edebali Üniversitesi, İslami ilimler Fakültesi, İslam Tarihi ve Sanatları Bölümü, Bilecik, Türkiye. E-posta: rabia.dogru@bilecik.edu.tr ORCID: 0000-0002-8344-0735

Atrf: Dogru, Rabia. "Yunus Emre'nin Şathiyelerini Bilinç Akışı ile Okumanın İmkânı Üzerine." darulfunun ilahiyat 32, 'Yunus Emre' Özel Sayısı (2021): 89-106. https://doi.org/10.26650/di.2021.32.991308 


\section{Extended Summary}

Various approaches have been proposed with regard to Yunus Emre's poetic thought process in relation to his poem "I climbed to the branches of a plum tree" and other shathiya-type poems. Some of Yunus Emre's poems are built on images that do not reconcile directly with one another in terms of their meanings and are distant from rationality; therefore, Yunus Emre's poems are typically received by readers differently compared to other literary works. With such images as the foundation, several approaches established around the poem "I climbed to the branches of a plum tree" are centered on the idea that Yunus Emre has employed symbolic language with a definite rationale in mind. The basis to such approaches is the inference that the depictions in Yunus Emre's poetry and all other shathiya-type poems have no apparent meaningful associations at first glance. Further, it is believed that these representations are intended as "symbolisms" allegorizing some other phenomenon. According to this view, the embedded phrases in the poem employ the concepts of Sufi philosophy extensively. Therefore, it is presumed that they are constructed with indicators of the conceptual universe.

The general characteristics of shathiya-type texts are as follows. The Arabic word shathiya means "quake, move, vibrate, and overflow," and it is derived from the root $s h-t-h$ (شطح). It is most commonly a Sufi phrase indicating very pompous and illogical remarks, which Sufis utter without comprehending shathiya-type texts' meaning. Shathiya, which are texts with oblique phrases recounting the poet's situations, use symbolic language. Commentaries are needed to enable optimal understanding of texts that require the reader to engage with the language at a level that goes beyond its practical application. However, these commentaries typically interpret Yunus Emre's poetry as based on the tenets of Sufi philosophy. Such limited consideration has spurred the emergence of a one-sided approach to Yunus Emre's poetry. We propose that the statement "Whatever Yunus says cannot be compared to other discourse" can, in fact, be perceived as an invitation for readers to defy the existing one-sided approach and establish different approaches to interpret his poetry that is typically distant from rationality. Ironically, the fact that Yunus Emre's poetry is distant from rationality, does not convey its meaning clearly at first glance, and "cannot be compared to other discourses" should be reason enough for readers to overthrow such one-sided discourses and realize the limitless scope of interpretation that Yunus Emre's poetry has to offer.

In this context, if readers rejected the predominant approach of considering Yunus Emre's poetry from a shathiya perspective and interpreted it differently, would they arrive at the inference that the "irrational" elements in Yunus Emre's poetry correspond to the characteristics of the stream-of-consciousness genre but without a direct indication to the idea being implied?. In other words, can the fact that Yunus Emre's poems entail words that do not directly reconcile with one another - typically taking the reader by surprise- 
enable readers to interpret such texts as works of stream-of-consciousness fiction? When Yunus Emre says "climbing to the branches of the plum tree and eating grapes," is he concurrently referring to his intellectual journey? Thus, can we observe Yunus Emre's stream of consciousness through the poetic images that noticeably do not reconcile with one another in terms of meaning? In such a case, can the readers, upon being confronted with the contradictory images in Yunus Emre's poems, journey to another realm of meaning by diverting themselves from the physical environments that surround them and merge with the intellectual environment of the poet's perpetual consciousness?

We assert that the poem with the line "I climbed to the branches of a plum tree" as well as other poems of the shathiya type might well be reflections of the relative disorganization in the speaker's consciousness (depending on the technique of stream of consciousness), and the thoughts in the speaker's consciousness might overflow and shake the poet (based on the meaning of shathiya). Thus readers ultimately transcend the symbolic implications of the text and arrive at the realm of alternative interpretation 
"Dilsüzler haberini kulaksuz dinleyesi Dilsüz kulaksuz sözin cân gerek anlayası"

(Yunus Emre)

\section{Giriş}

Yunus Emre'nin şathiye türündeki şiirleri ve bunlardan hareketle onun şiirsel düşünme tarzı hakkında çeşitli yaklaşımlar söz konusudur. Bilindiği üzere bu şiirler, birbiriyle anlam bakımından doğrudan uzlaşmayan, rasyonellikten uzak ve bu bağlamda farklı bir alımlama tarzını beraberinde getirmesi beklenen imgelerle kurulmuştur. Bu imgelerden yola çıkarak onun şathiyeleri hakkında öne sürülen yaklaşımların birçoğu, Yunus Emre'nin burada kasıtlı olarak sembolik bir dil kullandığ yönündedir. Yani söz konusu yaklaşımlarda, Yunus Emre'nin "çı1ktım erik dalına" şiirinde ve şathiye olarak değerlendirilen diğer şiirlerinde yer bulan; ilk bakışta aralarında anlamsal bir irtibat kurulamayan imgelerin, bir "gösterilen" olarak kurgulandığı ve başka bir şeye işaret ettiği şeklinde bir ortaklık bulunmaktadır. Buna göre, "çıktım erik dalına" şiiri, gösteren ve gösterilen olmak üzere ikili bir anlam dünyasını açığa çıkarmaktadır. ${ }^{1}$ Bir başka deyişle, şathiyelerde üstü örtülü bir şekilde verilen kelimelerin, derinde tasavvufî düşüncenin kavramlarını barındırdığı; böylece onun, kavramsal bir dünyanın gösterilenleriyle tasarlandığı varsayılmaktadır.

Şairin (mutasavvıfın) içinde bulunduğu halin üstü örtülü bir şekilde ifade edildiği bir metin olan şathiye, kullandığ 1 sembolik dil sebebiyle "işaret dili”, "agrebü'lgarâib", "mânâ dili" veya "kuş dili" olarak da nitelenmektedir. ${ }^{2}$ Dolayısıyla pratik dilin aşılarak kendisine özel bir dilin kullanıldığı belirgin olan bu tür metinlerin anlaşılması için şerhlere ihtiyaç duyulmuştur. Ne var ki bu şerhlerin çoğunlukla tasavvuf düşüncesinden hareketle yapılmış olması, Yunus Emre'nin bu türdeki şiirlerine tek yönlü yaklaşım alışkanlığını ${ }^{3}$ da beraberinde getirmiş gibidir. Oysa onun “Yunus bir söz söylemiş hiçbir söze benzemez” dizesi, Yunus’un söz konusu irrasyonel imgelerle örülü şiirlerine başka türlü yaklaşmak için kanaatimizce bir davet olarak yorumlanabilir. Nitekim söylenmiş bir sözün "hiçbir söze benzememesi", bu sözlerin, önceden belirlenip sınırlandırılmış anlam alanından uzaklaşarak

1 Burhanettin Tatar, "Yunus Emre'de Şiirsel Düşünme Biçimi”, Doğumunun 770. Yıldönümünde Uluslararası Yunus Emre Sempozyumu (İstanbul, 26-27 Kasım 2010), 69.

2 Cemal Kurnaz - Mustafa Tatc1, Türk Edebiyatında Şathiyye, (Ankara: Akçağ Yayınları, 2001), 29.

3 “...şiirleri kendi dışındaki (dış dünya) referanslara nispetle algılama alışkanlığı, şiirleri nesir'e indirgememize yol açmakta ve literal düşüncenin şiirsel düşünceye tahakküm etmesine neden olmaktadır.” Tatar, "Yunus Emre'de Şiirsel Düşünme Biçimi”, 71. 
okunmas1; dolayısıyla metnin farklı perspektiflerden algılanması hususunda okura bir çağrı olarak anlaşılabilir.

Bu bağlamda şathiyelere yönelik şimdiye değin benimsenen okuma alışkanlığını askıya alırsak ve onu başka türlü bir yaklaşımla okumayı denersek Yunus Emre'nin şiirlerindeki bu irrasyonel imgelerin, bir başka gösterilene işaret etmeden bir bakıma bilinç akışındaki seyrin ürünü olduğunu söyleyebilir miyiz? Daha açık bir deyişle, bu şiirlerin birbiriyle doğrudan uzlaşmayan ve bu bakımdan okuru bir şaşkınlığa sürükleyip deyim yerindeyse onu afallatan kelimelerle kurulmuş olması, söz konusu metne bilinç akışı kurgusuyla yaklaşmamıza imkân tanıyabilir mi? Yani söz gelimi Yunus Emre, “erik dalına çıkıp üzüm yemek”ten yahut "bir dem mescide girip yüzünü yere sürmek, bir başka dem ise kiliseye girip ruhban olmak"tan bahsederken söyleyicinin ${ }^{4}$ bilincinde beliren serüveni de aynı anda açığa çıkarıyor olabilir mi? Dolayısıyla biz, ilk elde anlam bakımından birbiriyle uzlaşmadığ fark edilen bu şiirsel imgelerde, söyleyicinin bilincindeki akışı ve -şathiye türünün "taşma" anlamından hareketle- okura değin uzanan bir taşmayı seyrediyor olabilir miyiz? Şayet bu olabilirse, Yunus Emre'nin şathiye türündeki şiirleri, önceki yaklaşımlardan farklı olarak muhatabına nasıl bir tecrübe yaşatabilir? Bununla birlikte bu şiirlerde tutarsız görünen imgelerle karşılaşan okurun, söyleyicinin bilincindeki sürekliliğe dahil olma arzusuyla bulunduğu ortamdan uzaklaşıp başka bir anlam dünyasına yolculuğu mümkün müdür?

Bizim bu yazıyla birlikte sunmaya çalışacağımız tez, Yunus Emre'nin şathiye olarak değerlendirilen şiirlerinin, -bilinç akışı tekniğinden hareketle- söyleyicinin bilincindeki görece dağınıklığın/çoğulluğun bir çeşit yansıması; -şathiyenin anlamından hareketle- onun bilincindeki şeylerin taşarak okura değin uzanması olabileceği; böylece okurun, sembolik bir anlam örgüsünün ötesinde alternatif bir anlam dünyasına ulaşabileceğidir.

\section{Bilinç Akışı Metinler ve Şathiye Türündeki Şiirler Arasındaki Benzerlik}

Bilinç akışının, belki en yalın tanımıyla "insanın gerçek hayatta olduğu gibi, her an aklından geçeni, zaman ve mekân kategorilerine bakmaksızın birinden

4 Buradaki "söyleyici” ifadesini, şiiri söyleyen; yani şairin ürettiği, o şiire özel olan kurgusal kişi için kullanıyoruz. "Her şiirde, belki de sanatkâr, düşünmeden bir söyleyiş yaratmaktadır. Bu söyleyici kendisi değildir. Yalnızca o şiir için yaratılmış kişidir. Görevi ve varlığı o şiir metnini söylemekten ibarettir. Konuşma esnasında konuya, hitap edilen kişiye, yere ve zamana göre ses tonu, vurgu ayarlandığı, kelimeler seçildiği gibi, şiirde de bu söyleyici, konuşma sentaksından hareketle, kendi kimliğine, zevkine ve anlayışına göre bir söyleyiş tarzı belirler. Bu söyleyiş tarzı metindeki birçok ögeyi şekillendirir ve etrafında toplar." Şerif Aktaş, Şiir Tahlili-Teori ve Uygulama-, (Ankara: Akçağ Yayınları, 2009), 40. 
ötekine çağrışım esasına dayalı geçişler şeklinde yansıtmak" olduğu söylenebilir. $\mathrm{Bu}$ yönüyle bilinç akışı, anlatıcının/söyleyicinin kafasında olup bitenleri okura doğrudan seyrettirmeyi deneyen bir teknik ${ }^{6}$ olarak kabul edilmektedir.

Bilinç akışı (stream of consciousness), psikoloji bilimi içerisinde William James tarafından üretilen bir terimdir. Zihinden geçen çok sayıda duygu ve düşünceyi görünür kılma arayışıyla bu teknik, edebiyat eleştirisinde mühim bir yer edinmiştir.? Lawrence Bowling, Dostoyevski'nin bilinç akışı konusundaki düşüncesini şu şekilde izah etmektedir: "Dostoyevski'nin gerçekte söylemek istediği şey şudur: zihnimizden geçen ve bizim genel olarak -düşünce- diye adlandırdığımız şeylerin pek çoğu aslında duyumlardır (ve imgeler), zihnimiz bunları hiçbir zaman dile çevirmez; bu duyumları ve imgeleri günlük -konuşma dili-ne geçirmek istediğimiz zaman çevirimiz tuhaf ve katı olur; eğer onları -yazınsal- dile çevirmeye çalışırsak sonuç daha az inandırıcıdır; kişiye -bütün- bilinçliliğini dille düşündüremeyeceğimize göre..." Bilindiği üzere, varlık tarzı itibarıyla insan, duygu ve düşüncelerini, dilin çeşitli şekilleriyle ifade etmek durumundadır. Ne var ki bilincin içerisinde bulunan her şeyin, tüm kapsayıcılığıyla dile getirilme imkânı bulunmamaktadır. $\mathrm{Bu}$ anlamda bilinen gramer kurallarından, alışılmış dil düzeninden, çizgisel bir zaman/ mekân algısından uzaklaşarak ve okuru da uzaklaştırarak yeni bir dil geliştirmeyi deneyen bilinç akışı, başka türlü anlama ve yorumlama açısından dikkate değer bir noktada durmaktadir.

Bilinç akışı tekniğiyle kurulan metinlerde pratikteki (reel) zaman ${ }^{9}$ ve mekân ilerleyişi gözetilmediğinden; bu metinler, ilk bakışta bize bir tutarsızlık ve dağınıklık içerisinde görünebilir. Nitekim bunlar, kurgusal diğer bazı metinlerde olduğu gibi bilinçteki tasarımları zamansal ve mekânsal açıdan sıralı/kurallı bir şekilde yansıtmamaktadır. Aksine bilinç akışıyla üretilen metinler, kişinin bilincindeki şeyleri -detayları kaçırmadan, karmaşasıyla birlikte- olduğu şekliyle okura sunmakta;

5 Gürsel Aytaç, Çağdaş Türk Romanı Üzerine İncelemeler, (Ankara: Doğu Batı Yayınları, 2016), 44.

6 Berna Moran, Türk Romanına Eleştirel Bir Bakış 1, (İstanbul: İletişim Yayınları, 1987), 75-76.

7 J. A. Cuddon, A Dictionary of Literary Terms and Literary Theory, (Wiley-Blackwell Publication, 2013), 682-683.

8 Lawrence E. Bowling, “Bilinç Akımı Tekniği Nedir?”, Yeni Dergi 8 (Mayıs 1965): 16.

9 “...bilinç akımı, kişinin dış dünyasında mevcut olan "reel zaman"dan çok, "zihinsel” bir aktiviteyi işaret eder. Yani bilinç akımı, zihinsel bir zamandır. Bu yüzden de herhangi bir kalıba sokulamaz. Bilinç akımının kalıba sokulamaması demek, reel zaman ölçütleriyle ifade edilememesi demektir. Reel zaman, "geçmiş", "şimdi" ve "gelecek" şeklinde kategorize edilebilir. Oysa bilinç akımı, bilincin zorunlu kıldığı bir "şimdiki zamanda", zihnin geçmişe ya da geleceğe yaptığı yolculuk demektir.” Şaban Sağlık, “Türk Öyküsünde Bir Anlatım Tekniği Olarak Bilinç Akımı”, Hece Öykü 26 (Nisan-Mayıs 2008): 52. 
dolayısıyla okur tarafindan ister istemez metindeki mantıksal bağın da doğrudan izlenememesi gibi bir durum açığa çıkmaktadır. Bunun yanı sıra böyle bir metnin okurunda, "bazen gizemli veya fantastik gibi, bazen de bir sembolist şaire veya deliliğin sınırlarını zorlayan birine ait karmaşık ve özel bir dünyada bulunulduğu izlenimi uyanmaktadır." 10

Bilinç akışında kullanılan araçlarla ilgili yapılmış bir çalışmada yer bulan "ertelenmiş bağdaşım" ilkesine göre, bilinç akışı metinlerinde, kurgunun belirli bir düzen içinde sunulmaması ve serbest çağrışımla oluşturulması söz konusudur. Böylece ilk bakışta mantıklı bir nedene bağlanamayan bir bağdaşımsızlık etkisi fark edilmektedir. ${ }^{11}$ Bununla birlikte bilinç akışı yazarı/şairi, normal (mantığa uygun) bir söz diziminin aksine; söze dökme eylemine "akla uydurma" sürecini karıştırmamaktadır. ${ }^{12}$ Yazarın, metni oluştururken mantıksal bir bağ kurmaya bir bakıma direnmesi; bilinç akışı yazarı ve kullandığı dil arasında bir gerilim bulunduğuna işaret etmektedir. Nitekim yazar, sözcük dokusunu birtakım kurallara göre düzenlemeye çabalamamakta ve dolayısıyla metnin, okur tarafından hızlı bir şekilde anlaşılması durumuyla ilgilenmemektedir. Dahası muhtemelen retoriği kasıtlı bozup beklentileri boşa çıkarmakta ve böylece okuru, anlam bakımından daha derine çekmektedir. ${ }^{13}$

Görebildiğimiz kadarıyla bilinç akışı tekniğinin genel karakteri bize, bu kurguyla üretilmiş metinlerin, şathiye türündeki şiirlerle benzerliğini göstermektedir. "Şathiye", kelime anlamı "sarsılma, hareket etme, titreme, taşma" olan Arapça "ş-t-h" (شطح) kökünden türemiştir. ${ }^{14}$ Daha ziyade tasavvufî bir 1stılah olarak "bazı mutasavvıfların vecd ve istiğrak halinde kendi iradeleri dışında, manasını düşünmeden söyledikleri, içinde bir iddia ve akla aykırı bir taraf bulunan ve dıştan, şeriata muhalif gibi görünen aşırı derecede söz" anlamında kullanılmaktadır. ${ }^{15}$ Şathiyeler, muhtevalarına göre üç kategoride değerlendirilmektedir: “1.Cem' makamındaki mutasavvıfların vecd ve istiğrâk hâlinde söyledikleri, zâhiren dinî ve şer'î inanışlara aykırı gibi görünen şathiyyeler. 2.Cennet arzusunu ve cehennem korkusunu aşan, bu duygularla kayıtlanan zâhid tipini alaya alan, bu tavrından dolayı

10 Serdar Odacı, "Ulysess ve Tutunamayanlar'da Bilinç Akışı Tekniğì”, Turkish Studies 4 (2009): 618.

11 Robert Humphrey, "Bilinç Akımında Kullanılan Araçlar”, Yeni Dergi 8 (Mayıs 1965): 25-26.

12 Humphrey, "Bilinç Akımında Kullanılan Araçlar", 33.

13 Necip Tosun, “Modernizmin Eleştirel Dili Bilinç Akımı”, Hece Öykü 26 (Nisan-Mayıs 2008): 41.

14 Kurnaz - Tatc1, Türk Edebiyatında Şathiyye, 3-4; Süleyman Uludağ, "Şathiye”, Türkiye Diyanet Vakfi İslam Ansiklopedisi, (İstanbul, 2010) 38: 370.

15 Kurnaz - Tatc1, Türk Edebiyatında Şathiyye, 4. 
dini inançlara saygısız sanılan bazı şathiyyeler, hiçbir kayıtla kayıtlanmayan bir aşkın samimi cüretkârlığı ve pervasızlığ 1 ile söylenmişlerdir. 3.Bazı şathiyyelerde, eşyanın mantığına ve insan aklına aykırı, saçma gibi görünen bir anlatım tercih edilerek muhatap tebessüme ve düşünmeye sevk edilir. Deli saçması veya çocuk tekerlemesi tarzında söylenen bu şathiyyeler, insan aklında alışılmamış bir sarsıntı meydana getirerek içindeki mânâyı araştırma ve anlama konusunda bir merak ve tecessüs uyandırır."

Fark edileceği üzere, metin kurulumu ve okurda oluşturduğu çağrışımlar bakımından şathiyeler, bilinç akışı metinleriyle benzerlik gösterir. Öyle ki "Çıktım erik dalına" şiirini şerh edenlerden biri olan Muhammed Niyâzî-i Mısrî (ö.1694), bu şiir tarzını "Gerçi görünüşte alay ve istihzaya ve çocuk eğlencelerine benzer ama bâtınen Allah gelinleri olan ilâhî sırlar ve hakikat mânâsı olan bâkirelerin yüzlerine nâ-mahremlerden örtmek için çekilmiş duvak ve nikâb gibidir. Tâ ki, nâ-mahrem gözü görmeye ve eli ermeye." ${ }^{17}$ şeklinde ifade etmiştir. Yani şathiyeler de ilk bakışta bilinç akışı metinlerindeki gibi anlaşılmaz bir tuhaflıkta görünmektedir. Hatta her ne kadar şathiyelerin irade dışı söylenmiş lafızlarla üretildiği belirtiliyorsa da Niyâzî-i Mısrî’nin şerhinden anladığımız kadarıyla şathiye türü metinlerin, bakire bir gelinin namahremden sakındığ 1 yüzü gibi kasıtlı bir örtülü ifadeye büründürülmesi söz konusudur. Çünkü şathiyelerde, derinde bulunan anlamın saklanması, en azından ilk elde kendisini ifşa etmemesi hedeflenmektedir. Bilinç akışı metnini kuran kişi için de benzer bir durum olduğu söylenebilir. Nitekim o da metnini kurarken her şeyden önce, okur tarafından anlaşılma veya okura belirgin bir anlam sunma gibi bir talepten/hedeften sıyrılmaktadır. Böylece şathiyelerde olduğu gibi, bilinç akışı metinleri de anlamını kendi içinde tutmakta ve alışılmışın dışında bir yaklaşımla okunup yorumlanmayı beklemektedir.

\section{Yunus Emre’nin Şathiye Türündeki Şiirlerini Bilinç Akışı ile Okuma Denemesi}

Bilinç akışı tekniğiyle kurgulanmış metinlerin genel karakterinden hareketle, Yunus Emre'nin şathiye türündeki şiirlerini okumaya çalıştığımızda; bu şiirlerde, bilinç akışı örgüsünü çağrıştıran imgeler karşımıza çıkmaktadır. Söz gelimi aşağıda bazı beyitlerine yer verdiğimiz "Çıktım erik dalına" şiirinde tercih edilen kelimeler arasında doğrudan kurulacak mantıksal bir bağdan söz etmek mümkün görünmemektedir.

16 Kurnaz - Tatc1, Türk Edebiyatında Şathiyye, 36-45.

17 Kurnaz - Tatc1, Türk Edebiyatında Şathiyye, 30. 
"Çıkdum erik talına anda yidüm üzümi

Bostân ıssı kaklyup dir ne yirsün kozumı

Bir sinek bir kartalı kaldurup urdı yire

Yalan degül gerçekdür ben de gördüm tozını

Balık kavaga çıkmış zift turşısın yimege

Leylek koduk togurmış bak a şunun sözini

$\ldots$

Bir öküz bogazladum kakıldum sere kodum

Öküz issl geldi eydür bogazladun kazumı" 18

Bilindiği üzere bu şiirdeki kelimelerin birbiriyle uzlaşmaması durumu, genellikle tasavvuf düşüncesi bağlamında, Yunus Emre'nin bilhassa şathiyelerinde sembolik bir dil kullanmasıyla izah edilmiştir. Buna göre şair, erik dalına çıkarak orada üzüm yediğini yahut o anda bahçenin sahibinin kişiye ceviz yeme sebebini sorarak onu azarladığını söylerken aslında başka şeyler söylemeye çalışmakta ancak bunu, çeşitli sebeplerle üstü örtülü bir şekilde yapmaktadır. Bir diğer deyişle şair, ilâhî hakikatleri, anlamı sadece sülûk ehli tarafından bilinebilecek remizlerle/sembollerle ifade etmektedir. ${ }^{19}$

Bilinç akışı tekniği üzerine çalışmaları bulunan Humphrey, -bu tür şiirlerde kullanılan ve birbiriyle tutarsız görünen imgeler gibi- bağdaşım kurulamayan söz sanatlarına, "bilinçlilik süreçlerinin, dolaysız iletişim için özellikle perdelenmedikleri zamanlar, bölük pörçük, görünüşte bağdaşımsız, parçalanmış dokusunu tekrar meydana getirme" çabasıyla başvurulduğunu belirtir. ${ }^{20}$ Yani aslında kurgusal bir metinde karşımıza çıkan ve yazar/şair tarafından kurgu sırasında oluşturulmaya çalışılan mantıksal tutarlılık, söz dizimindeki uygunluk yahut çizgisel zaman ve mekânı yakalama gayreti, bir bakıma anlatıcının/söyleyicinin bilinçlilik sürecinin perdelenmesi anlamına gelmektedir.

Benzer şekilde şiirin devamında okuduğumuz, bir sineğin bir kartalı kaldırıp yere vurmas1, hatta söyleyicinin de çıkan toza varıncaya değin bu hadiseyi görmesi, şiirin mekânı olarak pratikteki mekân akışının gözetilmediğini açık etmektedir. Dolayısıyla ne şiirdeki hadiselerde ne de hadiselerin kurgulandığı mekânda bir tutarlılık mevcuttur. Nitekim bir diğer beyitteki kavağa çıkan balık imgesi, balığ1 yaşadığı mekândan koparıp onu kavak ağacına çıkararak okurdaki olağan mekân

18 Mustafa Tatc1 (Haz.), Yunus Emre Dîvân ve Risâletü'n-Nushiyye”, (İstanbul: Sahhaflar Kitap Saray1, 2005), 335-336.

19 Mustafa Tatc1, Yunus Bir Söz Söylemiş Çıktım Erik Dalına Şerhi, (İstanbul: H Yayınları, 2020), 19-21.

20 Humphrey, "Bilinç Akımında Kullanılan Araçlar", 32. 
algısını tepetaklak etmektedir. Bu türdeki karmaşı ve düzensiz ifadelerle karşılaşan okur, bir süre sonra kendisini metin içerisindeki hadiselerden kaçınılmaz olarak uzaklaştırmakta; böylece olaylardan ziyade açığa çıkan çağrışımları ve duyguları izleme imkânı bulabilmektedir. ${ }^{21}$

Böylesine birbiriyle bağdaşmayan ve daha ilk bakışta okuru şaşırtan imgelerin ardından Yunus Emre, söylediği sözlerin akla uymadığını "bak a şunun sözini" (şunun sözüne bakar mısın?!) ifadesiyle dile getirmektedir. Bu durumda söyleyici, önceki söylediklerine bir bakıma kendisi de şaşırarak bir anda yabancılaşmakta ve muhatabına da benzer bir tecrübe yaşatmaktadır. ${ }^{22}$ Yani okurun, bu şiirle karşılaşmadan önce çizgisel bir zaman ve mekân içerisinde süren aşinalık durumu, birdenbire zamanın ve mekânın bulanıklaştığı bir duruma dönüşüyor gibidir. Böylece kişi, içinde bulunduğu dünyayı anlamlandırma sürecini yeniden düzenleyerek başka türlü bir algılayış keşfedebilir. Dolayısıyla şiir içerisindeki bu şaşırtıcı imge kurgusu, bir durumun kavranmasını kolaylaştırmaktan ziyade, onun özel bir tarzda ve daha önce olduğundan farklı bir biçimde algılanması için güçlü bir deneme sayılabilir. ${ }^{23}$

Yunus Emre'nin, genellikle tasavvuf düşünce sistemi içerisinde ve vahdet-i vücûd, a'yân-1 sâbite, cem' gibi kavramlarla şerh edilen bir başka şiirinden bazı beyitler şöyledir:

"İy yârânlar iy kardaşlar sorun bana kandayıdum

Dinlersenüz eydivirem ezelî vatandayıdum

Eyyûb'lla derde esîr iniledüm çekdüm cezâ

Belkîs'ıla taht üzere mühr-i Süleymân'dayıdum

Yunus'ila balık beni çekdi deme yutdı bile

Zekeriyyâ'yıla kaçdum Nûh'ıla tûfândayıdum

'Asâyıla Mûsâ'yıla kaçdum çıkdum Tûr Tagı'na

İbrâhîm'ile Mekke'ye bünyâd biragandayıdum

İsmâ'île çaldum bıçak bıçak ana kâr itmedi

Hak beni âzâd eyledi koçıla kurbândayıdum

21 Tosun, "Modernizmin Eleştirel Dili Bilinç Akımı”, 39.

22 Nitekim güçlü imgelerle kurulmuş bir şiir, okuruna "yadırgatıcı" ve "yabancılaştırıcı" bir etki alanı açmaktadır. Emine Tuğcu, Osmanlı’nın Son Döneminde Şiir Eleştirisi, (İstanbul: İletişim Yayınları, 2013), 16-17; Terry Eagleton, Edebiyat Kuramı, çev. Tuncay Birkan, (İstanbul: Ayrıntı Yayınlar1, 2011), 18.

23 Boris Eyhenbaum, ““'Biçimsel Yöntem”in Kuramı”, Yazın Kuramı: Rus Biçimcilerinin Metinleri, ed. Tzvetan Todorov, çev. Mehmet Rifat-Sema Rifat, (İstanbul: Yapı Kredi Yayınları, 2016), 59. 
Yûsuf'ıla ben kuyıda yatdum bile çekdüm cezâ

Ya'kûb'ıla çok agladum bulınca figândayıdum

'Alî'yile urdum kilıç Ömer'ile 'adl eyledüm

On sekiz yıl Kâf Tagında Hamza'yla meydândayıdum,"24

Bu şiiri bilinç akışı kurgusuyla okumayı denediğimizde, yine bir mekân ve zaman tutarsızlı̆̆ı karşımıza çıkmaktadır. Söyleyici okura hitap ederek şiire başlamakta ve "sorun bana kandayldum" (sorun bana neredeydim) diyerek dikkatleri "nerede" olduğuna, yani bulunduğu mekâna çekmektedir. Ancak peşi sıra kendisini konumlandırdığı mekânları ve çizgisel zamanı aşarak yaptığı yolculukları şiire konu etmektedir. Yani "sorun bana neredeydim" ifadesiyle karşılaşarak belirgin ve yerleşik bir mekân bilgisine ulaşmayı bekleyen okurun beklentisi, bir bakıma boşa çıkmaktadır. Çünkü söyleyici, okurun bu beklentisine cevap vermemekte ve onu, hızlıca yeni bir alımlamaya mecbur bırakmaktadır. Böylece çizgisel bir zamanda yaşayan okuru, sürekli sapmaların baş gösterdiği; zamanın ve dilin çizgisel seyrinin bozulduğu bir anlam dünyasına taşımaktadır.

Yunus Emre'nin,

"Ben bu cihana gelmedin sultân-ı cihândayldum

Sözi gerçek hükmi revân ol hükm-i sultândayıdum "25

şeklinde yine zaman ve mekân ötesini ifade eden imgelerle başlayan şiiri,

"Yunus bu cümle varlıgun dost katında zerre degül

Güftile kelâmdayıdum hem bunda hem andayıdum"26

beytiyle son bulmaktadır. Şiirin bilhassa son beytindeki "hem bunda hem anda" (hem burada hem orada) ifadesi dikkat çekici görünmektedir. Zira bilinç akışı metinlerinde, bilincin bir "an" üzerinde derinleşebildiğine tanık olmaktayız. Bilincin, bir taraftan içinde bulunulan anda yaşaması, diğer taraftan aynı anda geçmişe dair hatırlamalarda ve geleceğe dair tasarımlarda bulunması, aynı zamanda da çevreyle ve eşyayla irtibat halinde olması söz konusudur. Bu bağlamda bilinç akışını sadece bir anlatım tekniği olarak ele almak, eksik bir bakış açısı olacaktır. ${ }^{27}$ Nitekim bilinçteki geçmiş, şimdi ve gelecek arasındaki bağı muhafaza etmeyi deneyen bilinç akış1, bir anlatım tekniği olmanın ötesinde insana bir "bütün" olarak bakabilmenin kapısını aralamaktadır. Bu bütünlük, insanın dünyadaki varoluşunu aşan bir tarzda da olabilir. Söz gelimi bu şiirde söyleyicinin, "Ben

24 Tatc1, Yunus Emre Dîvân, 187.

25 Tatc1, Yunus Emre Dîvân, 189.

26 Tatc1, Yunus Emre Dîvân, 190.

27 Rasim Özdenören, Ruhun Malzemeleri, (İstanbul: İz Yayıncılık, 2009), 108. 
bu cihana gelmedin sultân-ı cihândayıdum " diyerek dünya serüveninden önceki yolculuğundan bahsetmesi, bize ilk elde insanın yaratılış sürecindeki sözleşmesini bildiren ayeti ${ }^{28}$ çağrıştırmaktadır. Yani dünyada yaşayan bilinç, bu şiir üzerinden, bir bakıma dünyaya gelmeden önceki zamanı ve mekânı da içine alabilen bir sürece aynı anda tanıklık edebilmektedir. Dolayısıyla insan bilincinin, yaşadığı anda kalarak kendisinin bile hatırlamadığı bir zamana ve mekâna uzanmaya çalışması; bilinç akışından hareketle insanın varoluşuna bir bütün olarak yaklaşabilmenin imkânını bize açıkça göstermektedir.

Bunun yanı sıra "gönül” üzerinden insanın hızla halden hale geçişinin anlatıldığı aşağıdaki şiirde de söz konusu bütünlüğe ulaştıracağı düşünülen bilinç akışı öğelerini görmek mümkündür.

"Hak bir gönül virdi bana hâ demedin hayrân olur Bir dem gelür şâdî olur bir dem gelür giryân olur

Bir dem sanasın kış gibi şol zemherî olmış gibi

Bir dem beşâretden togar hoş bâgıla bostân olur

Bir dem gelür söyleyemez bir sözi şerh eyleyemez

Bir dem dilinden dür döker dertlülere dermân olur

Bir dem çıkar 'Arş üzere bir dem iner tahte's-serâ

Bir dem sanasın katredür bir dem taşar 'ummân olur

Bir dem cehâletde kalur hîç nesneyi bilmez olur

Bir dem talar hikmetlere Câlinûs u Lokmân olur

Bir dem gelür 'âsî olur Hak zihnini yavı kılur

Bir dem gelür kim yoldaşı hem zühd ü hem îmân olur

Bir dem varur mescidlere yüzin sürer anda yire

Bir dem varur deyre girer İncîl okur ruhbân olur

$\cdots$

Bir dem döner Cebrâil' 'e rahmet saçar her mahfile

Bir dem gelür güm-râh olur miskîn Yunus hayrân olur'"29

28 'Rabbin Âdemoğulları'ndan -onların sırtlarından- zürriyetlerini alıp bunları kendileri hakkındaki şu sözleşmeye şahit tutmuştu: Ben sizin Rabbiniz değil miyim? 'Elbette öyle! Tanıklık ederiz' dediler. Böyle yaptık ki kıyamet gününde, 'Bizim bundan haberimiz yoktu demeyesiniz.'” A'râf 7/172. Beyitteki “Güftile kelâmdayıdum” ifadesi, insanın Rabbi ile kurduğu bu sözleşmenin habercisi gibi okunabilir.

29 Tatc1, Yunus Emre Dîvân, 117-118. 
Bazı beyitlerini alıntıladığımız Yunus Emre'nin bu şiiri, tasavvuf düşüncesindeki telvîn-temkîn ${ }^{30}$ kavramları üzerinden sâlikin tecrübe ettiği manevî hallerle ${ }^{31}$ şerh edilegelmiştir. Bilindiği üzere insan bilinci, daima bir şey düşünen ve bu düşünce akışı durdurulamayan bir yapıdadır. Öyle ki söyleyicinin, bir an mutlu olup bir an üzgün olmasi; bir an cahil olup bir an hikmetlere ermesi; bir an isyan içinde olup bir an inançla dolması gibi birbiriyle uzlaşmayan çeşitli halleri aynı kişinin "an” lık değişimlerle tecrübe ettiği durumlar olarak ifade etmesi, bu durdurulamazlığa açik bir işarettir.

Bununla birlikte görebildiğimiz kadarıyla Yunus Emre bu şiirinde, içinde bulunduğu dünyayı zıtlıklar üzerinden anlamaya çalışmaktadır. Yani pratik hayatta bir arada bulunması mümkün olmayan çeşitli zıtlıkları birbirine bağlayarak bütün olanı görmeyi denemektedir. Nitekim son beyitte ifade edilen "miskîn Yunus hayrân olur" sözü de çoğulluğun/dağınıklığın kucaklanmasıyla belirmiş bir bütünlük ve bu bütünlüğün tecrübe edilmesinden doğan bir hayranlık olarak okunabilir.

"Evvel kadîm önden sona zevâli yok sultân benem

Yidi iklime hükm idüp yiri gögi dutan benem

Ben bu yiri yaradicak yir üstine gök turicak

Ulu deniz mevc uricak Nûh'a tûfân viren benem

Sofìylan sofì olan sûfîyile sâfì olan

Bel baglayup tâ'at kulan o Kerîm ü Rahmân benem

Ben 'âbidem ben ma'bûdam kamu yirlerde hâzıram

Zâlimlerden dâd alıcı miskinleri dutan benem "'32

"Ol Kâdir-i Kün feyekûn lutf idici Sübhân benem

Kesmedin rızkın viren cümlelere sultân benem

$\cdots$

Hem bâtınam hem zâhirem hem evvelem hem âhirem

Bu cümlesini yaradup hem tertibi kllan benem

...

Bu yiri gögi yaradan bu 'Arş̧ı Kürs'i durudan

Bin bir adı vardur Yunus ol sâhib-i Kur'ân benem,'33

30 "Renkten renge girme ve mekân tutma anlamlarında Arapça iki kelime. Telvîn, bir halden diğer hâle geçmeyi veya bir makamdan diğer bir makama atlamayı ifade eder. Temkîn ise, istikâmette derinleşmek ve sabitleşmek anlamına gelir. İkisi birbirinin mukabili gibidir.” Ethem Cebecioğlu, Tasavvuf Terimleri ve Deyimleri Sözlüğü, (İstanbul: Anka Yayınları, 2005), 649.

31 Mustafa Tatcı, Yunus Emre Dîvânı Tahlil, (İstanbul: Milli Eğitim Bakanlığı Yayınları, 2005), 256.

32 Tatc1, Yunus Emre Dîvân, 206.

33 Tatc1, Yunus Emre Dîvân, 217-218. 
İlk bakışta okuru afallatan bu "benem" redifli şiirlerde, söyleyicinin, yaratıcının diliyle konuştuğu fark edilmektedir. Şerh geleneğine bakıldığında bu şiirler, yine tasavvuf düşünce tarzı içerisinde anlaşılmış ve "fenâ fi' 'llâh" kavramı üzerinden değerlendirilmiştir. Diğer yandan bu beyitleri bilinç akışı üzerinden okumaya çalıştığımızda; şairin, muhtemelen insan ve Tanrı arasındaki ontolojik farklılığı, Tanrı'ya özgü eylemleri/sıfatları insana ait kılmak gibi bir tutarsızlıkla açık etmeye çalıştığını söyleyebiliriz. Yani beliren bu tutarsızlık, şairin, insan ve Tanrı'nın birbirinden farklı olan ontolojisini kavrama çabası olarak okunabilir. Nitekim insan bilinci, mahiyeti itibarıyla söz konusu çabanın kendisini gösterebildiği ayrıcalıklı bir alandır. Daha açık bir deyişle bilinç, bir yandan insan olmanın tecrübesinin sürdüğü diğer yandan Tanrı'nın dilinin ödünç alınarak ilâhî bir varlığın tecrübesine ulaşmanın, O'nun mahiyetiyle tanışmanın denendiği bir eşik olabilir. Zira "sınırın tecrübesi, her doğrulama imkânsız olacak derecede, sınırın ötesinde gerçekleşir." ${ }^{34}$ Dolayısıyla şair, insan ve Yaratıcı arasındaki ontolojik farklılığ anlamak için -bilinç yahut dil üzerinden geliştirdiği sınır tecrübesiyle- kendisine bir yüzleşme/tanışma alanı inşa edebilir. Bunun yanı sıra inanan kişinin bilinci, Tanrı'yla kurduğu bağı, kişinin bir başka kişiyle olan diyaloğu gibi düzenlemek istediği için bu bilincin, birbiriyle kolayca uzlaştırılamayan gerçeklikler arasında mecburen bölünmüşlüğü söz konusu olabilmektedir. ${ }^{35}$ İnanan kişinin içinde bulunduğu bu dramatik durum, onu, Tanrı'yı yahut tanrısallığı anlama konusunda farklı bir düşünce veya dil geliştirmeye yöneltebilir.

Bunun gibi örnekler, her şeyden önce söyleyicinin bilincindeki takip edilemez hareketliliğin/sürekliliğin bir şekilde dile transfer edilme çabasını akla getirmektedir. Bu sürekliliğin yansıtılması, bilincin içerisinde aynı anda beliren birçok şeyin hem zamansal hem de mekânsal açıdan görece dağınık bir biçimde metne taşınması olarak kendini göstermektedir. Dolayısıyla bu durum, okuru olarak bize ilk elde anlaşılmaz ve boşlukta uçuşan olaylarla karşı karşıya olduğumuz bir tecrübe yaşatabilir.

Bilindiği üzere bilinçteki düşüncelerin/duyumların, olduğu gibi gündelik dile aktarılması dilin sınırlılığı sebebiyle pek mümkün değildir. Bu durum biraz da Deleuze'ün sinemayla ilgili yaptığı çalışmasında, değerlendirdiği filmlerden alınmış görüntüleri kasıtlı olarak kullanmayışına benzemektedir. Nitekim o, sinemada açığa çıkan "hareket imgesi”nin tek bir anı gösteren bir görüntüyle karşılanamayacağını düşünür. Çünkü filmlerde, akış içerisinde ortaya çıkan bir eylemin, tek bir görüntü içerisinde dondurulmasının yanıltıcı olduğu kanaatindedir. ${ }^{36}$ Hareketliliği aralıksız

34 Georges Gusdorf, İnsan ve Tanrı, çev. Zeki Özcan, (Bursa: Emin Yayınları, 2012), 108.

35 Gusdorf, Insan ve Tanrl, 98.

36 Özgür Taburoğlu, Resim, Söz ve Yazı İmge Yaratmanın ve Bozmanın Yolları, (Ankara: Doğu Batı Yayınları, 2013), 14. 
sürdüren bilincin, çizgisel bir dil ve zamanla ifade edilmesinde de benzer bir yanılgıyla karşı karşıya kalındığından söz edilebilir. Bu durumda dilin bilinçte eş zamanlı gerçekleşen deneyimleri tam anlamıyla ifade edememesi, bilinçte olup bitenleri bir bakıma kesintiye uğratarak okura yansıtmaya çalışması ve böylece bilincin sürekliliğini yakalayamıyor olması, kurgusal bir metin açısından bilinç akışını bizim için daha etkili ve cazibeli bir yöntem haline getirebilir.

Ancak diğer yandan bilincin sürekliliğini yansıtmaya çalışan metinler, okur için girift ve kimi zaman da anlamsız bir kelime yığını olarak bir süreksizlik içinde görünmektedir. Nitekim bilincin, -kendisini bir şey düşünmezken bulamaması anlamında- kesintiye uğrama imkânı bulunmayan bir yapıda olmasına karşın; onu dışarıdan seyreden kişinin, karşılaştığı şeyleri kendi tarihsel tecrübesinden hareketle yahut çeşitli önyargılar üzerinden algılaması, ister istemez bilinçteki akışın sürekliliği ile ona parçalı bakan kişinin seyrettiği süreksizlik arasında görece bir tezat doğurmaktadır. Daha açık bir deyişle bilinçteki sürekliliği yansıtmayı deneyen bir metin karşısında okur, dağınık gibi görünen mantıksal bağları doğrudan kuramadığı ve kurgusal zaman/mekân örgüsünü aynıla yakalayamadığı için kendisi ve metin arasında bir uyumsuzluk/çelişki bulunduğunu düşünebilir. Bu anlamda Yunus Emre "Ben söylerem ben dinlerem kimse dilüm bilmez benüm" ${ }^{37}$ derken bu tarz imgesel şiirlerinin başkaları tarafindan pek anlaşılmadığına, adeta kendisini anlayacak tek kişinin yine kendisi olabileceğine atıfta bulunuyor gibidir. Ayrıca bu şiirlerde kullandığı dilin günlük, anlaşılır ve perdesiz dilden uzak; özel bir dil olduğunu, aynı şiirde "Benüm dilüm kuş dilidür" diyerek de ifade etmektedir. Bununla birlikte Yunus Emre'nin aşağıdaki beyti, yine onun çevresi tarafından anlaşılmadığını vurgular niteliktedir:

"Yunus Emrem kimseler hîç bilmedi hâlüm benüm

Hâlümi 'arz itmeğe bir merd-i 'irfân isterem" ${ }^{38}$

Bu tür şiirlerin, muhatabı/okuru tarafindan kolaylıkla anlaşılmamasının, büyük oranda şairin şathiyelerinde kullandığı dil tarzından kaynaklandığını söyleyebiliriz. Bilindiği gibi pratik dilde yahut istisnalar olmakla birlikte genel olarak nesir dilinde, kullanılan dili büyük oranda görmezden gelmekteyiz. Söz gelimi birbirimize bir şeyler söyledikten veya bir nesir metni ortaya koyduktan sonra dinleyici/okur bu söylenenleri anlıyorsa artık o kelimelerin yıkılmış olduğunu fark edebiliriz. Yani bu kelimeler, bir başka şeye işaret etmiş ve anlamı belirginleştirmiş olmakla birlikte adeta gözden kaybolur. Zira muhatabımızın söylediklerini kavradıktan sonra karşılaştığımız kelimelerin aradan çekilmesi ve yerini, onun muadili anlamlara

37 Tatc1, Yunus Emre Dîvân, 191.

38 Tatc1, Yunus Emre Dîvân, 227. 
yahut görüntülere bırakması söz konusudur. ${ }^{39}$ Oysa anlamını ifşa etmeyen ve orijinal imgelerle kurulmuş bir şiir dili, okuruna böyle bir deneyim yaşatmaktan çok uzaktır. Okuru, önceden hedeflenip belirlenmiş bir anlama taşımanın ve kelimeleri aradan çıkarmanın aksine; böylesi bir şiir dili, okurunu, tam da kelimelerin içinde tutacaktır. Böylece kelimeler, okura hızlıca bir anlam transferi yaşatıp aradan çıkarılmak yerine tekrar tekrar kendi gücünü gösterme ve onu, sürpriz anlamlara taşıma imkânı bulacaktır.

Her ne kadar mantıksal bir zemin veya takip edilebilir bir zaman ve mekân içerisinde inşa edilmeyişleri, okur tarafından anlaşılması konusunda risk oluşturuyorsa da bu tür metinler, okuru, bulunduğu ortamdan alarak zamanın ve dilin çizgiselliğinin bulunmadığ 1 bir anlam dünyasına çekmeyi denemektedir. Dolayısıyla okur, böyle bir metinle karşılaştı̆ıında anlamı işaretleme yahut belirginleştirme çabasına girmeden, çekildiği anlam dünyasına kendisini bırakması mümkün olabilir.

\section{Sonuç}

Bu çalışmamızda, Yunus Emre'nin şathiye türündeki şiirlerini bilinç akışı ile okumanın imkânı üzerinde durduk. Şathiyelerin ve bilinç akışı metinlerinin benzerliklerinden hareketle yaptığımız okuma denemesinde karşımızda beliren ilk şey; Yunus Emre'nin burada örneklerine yer verdiğimiz şathiye türündeki şiirlerinin, bilinç akışı metinlerinde olduğu gibi rasyonellikten uzak ve birbiriyle anlam bakımından doğrudan uzlaşmayan imgelerle kurulmuş olmasıdır.

Bu durum, Yunus Emre'nin söz konusu şiirleriyle karş1laşan kişiye, ilk elde bir yabancılaşma tecrübesi yaşatmakta ve metni farklı bir tarzda alımlama noktasında onu harekete geçirmektedir. Böylece kişi, metinde söylenenlerden ziyade, öncelikle duyguları ve çağrışımları izleme imkânı bulmaktadır. Bunun yanı sıra bilinçte bulunan geçmiş, şimdi ve gelecek arasındaki bağı muhafaza etmeyi deneyen bilinç akışı, sunduğu "iç içe" zaman algısı ve çoğulluğu/ dağınıklığı aynı anda bir arada tutmayı denemesiyle, insana "bütün" olarak bakabilmenin kapısını aralamaktadır. Ayrıca farklı varlık tarzlarını yine zıtlıklar ve tutarsızlıklar üzerinden anla(t)mayı deneyen bu şiirler, okura da zıtlıklardan hareketle bir "bütünlük” tecrübesi yaşatmaktadır. Yunus Emre'nin bu şiirlerinde güçlü imgelerle karşımıza çıkan kelimeler, kavramsal anlam alanına bir gönderme yapmadığından okura hızlıca bir anlam transferi yaşatıp aradan çekilmemekte; aksine bu kelimeler, tekrar tekrar kendi gücünü gösterip kişiyi sürpriz alanlara ulaştırabilmektedir.

39 Paul Valery, Şiir Sanatı, çev. Ahmet Ölmez, (İstanbul: Ketebe Yayınları, 2020), 79. 
Sonuç olarak Yunus Emre'nin, yazımızda yer verdiğimiz şathiye türündeki şiirlerinde olduğu gibi, dile getirme eylemine mantıksal bağları kurma sürecinin karıştırılmaması ve çizgisel zaman-mekân algısının gözetilmemesi; okuru, anlamı belirginleştirme çabasından uzak tutmakta ve onu, çizgisel seyrin bulunmadı̆̆ 1 alternatif bir anlam dünyasına taşıyabilmektedir.

\footnotetext{
Hakem Değerlendirmesi: Dış bağımsız.

Çıkar Çatışması: Yazar çıkar çatışması bildirmemiştir.

Finansal Destek: Yazar bu çalışma için finansal destek almadığını beyan etmiştir.
}

Peer-review: Externally peer-reviewed.

Conflict of Interest: The author has no conflict of interest to declare.

Grant Support: The author declared that this study has received no grant support.

\section{Kaynakça/References}

Aktaş, Şerif. Şiir Tahlili -Teori ve Uygulama-. Ankara: Akçağ Yayınları, 2009.

Aytaç, Gürsel. Çağdaş Türk Romanı Üzerine Incelemeler. Ankara: Doğu Batı Yayınları, 2016.

Bowling, Lawrence E. “Bilinç Akımı Tekniği Nedir?”. Yeni Dergi 8 (Mayıs 1965), 10-22.

Cebecioğlu, Ethem. Tasavvuf Terimleri ve Deyimleri Sözlüğü. İstanbul: Anka Yayınları, 2005.

Cuddon, J. A. A Dictionary of Literary Terms and Literary Theory. Wiley-Blackwell Publication, 5th ed., 2013.

Eagleton, Terry. Edebiyat Kuramı. Çev. Tuncay Birkan. İstanbul: Ayrıntı Yayınları, 2011.

Eyhenbaum, Boris. ““Biçimsel Yöntem”in Kuramı”. Yazın Kuramı: Rus Biçimcilerinin Metinleri, Ed. Tzvetan Todorov. Çev. Mehmet Rifat-Sema Rifat, İstanbul: Yap1 Kredi Yayınları, 2016, 31-70.

Gusdorf, Georges. İnsan ve Tanrı. Çev. Zeki Özcan. Bursa: Emin Yayınları, 2012.

Humphrey, Robert. "Bilinç Akımında Kullanılan Araçlar”. Yeni Dergi 8 (Mayıs 1965), 23-37.

Kurnaz, Cemal ve Tatc1, Mustafa. Türk Edebiyatında Şathiyye. Ankara: Akçağ Yayınları, 2001.

Moran, Berna. Türk Romanına Eleştirel Bir Bakış 1. İstanbul: İletişim Yayınları, 1987.

Odac1, Serdar. “Ulysess ve Tutunamayanlar'da Bilinç Akışı Tekniği”. Turkish Studies 4 (2009), 605-684.

Özdenören, Rasim. Ruhun Malzemeleri. İstanbul: İz Yayıncılık, 2009.

Sağlık, Şaban. “Türk Öyküsünde Bir Anlatım Tekniği Olarak Bilinç Akımı”. Hece Öykü 26 (NisanMayıs 2008), 49-64.

Taburoğlu, Özgür. Resim, Söz ve Yazı İmge Yaratmanın ve Bozmanın Yolları. Ankara: Doğu Batı Yayınları, 2013.

Tatar, Burhanettin. "Yunus Emre'de Şiirsel Düşünme Biçimi”. Doğumunun 770. Yıldönümünde Uluslararası Yunus Emre Seтроzуити (26-27 Kasım 2010), İstanbul, 68-71.

Tatcı, Mustafa. Yunus Emre Dîvânı Tahlil. İstanbul: Milli Eğitim Bakanlığı Yayınları, 2005.

Tatc1, Mustafa (Haz.). Yunus Emre Dîvân ve Risâletü’n-Nushiyye. İstanbul: Sahhaflar Kitap Sarayı, 2005. 
Tatc1, Mustafa. Yunus Bir Söz Söylemiş Çıktım Erik Dalına Şerhi. İstanbul: H Yayınları, 2020.

Tosun, Necip. "Modernizmin Eleştirel Dili Bilinç Akımı”. Hece Öykü 26 (Nisan-Mayıs 2008), 39-48.

Tuğcu, Emine. Osmanlı'nın Son Döneminde Şiir Eleştirisi. İstanbul: İletişim Yayınları, 2013.

Uludağ, Süleyman. "Şathiye”. Türkiye Diyanet Vakfi İslâm Ansiklopedisi. 38: 370-371. İstanbul 2010.

Valery, Paul. Şiir Sanatı. Çev. Ahmet Ölmez. İstanbul: Ketebe Yayınları, 2020. 